\title{
Spatial ecology and multi-scale habitat selection by Western Painted Turtles (Chrysemys picta bellii) in an urban area
}

\author{
Kelsey A. Marchand ${ }^{1}$, Christopher M. Somersi ${ }^{1}$, and Ray G. Poulin ${ }^{2}$, * \\ ${ }^{1}$ Department of Biology, University of Regina, Regina, Saskatchewan S4S 4H4 Canada \\ ${ }^{2}$ Royal Saskatchewan Museum, 2340 Albert Street, Regina, Saskatchewan S4P 2V7 Canada \\ ${ }^{*}$ Corresponding author: ray.poulin@gov.sk.ca
}

Marchand, K.A., C.M. Somers, and R.G. Poulin. 2018. Spatial ecology and multi-scale habitat selection by Western Painted Turtles (Chrysemys picta bellii) in an urban area. Canadian Field-Naturalist 132(2): 108-119. https://doi.org/10.22621/cfn. v132i2.2036

\begin{abstract}
As urban centres expand, knowledge on the habitat and space use of native wildlife, particularly long-lived species, is required for proper management. Our objective was to understand space requirements and key habitat features necessary for long-term persistence of Western Painted Turtles (Chrysemys picta bellii) living in a Canadian urban park. Using radio telemetry, we examined seasonal habitat selection and space use over two years, 2015-2016 $(n=23)$, and 2016-2017 $(n=29)$ in Regina, Saskatchewan. Daily movements and home ranges of males and females were smaller during emergence than during nesting or post-nesting phases of the active season. Turtles inhabiting marsh sites had 2- and 4-times larger daily movements and home ranges compared to turtles inhabiting the creek. Turtles selected the shoreline habitat over urban/parkland and open water. Turtles used marsh-shoreline habitats non-randomly, selecting accessible shoreline with large trees in the active season. In contrast, turtles used creek-shoreline habitat according to availability. Overwintering sites selected by turtles were warmer and deeper than random available sites, with no difference in dissolved oxygen level. However, water was hypoxic for most overwintering sites. Our results show that turtles range widely, requiring 20-60 ha throughout the year. Urban park areas should be managed to provide accessible shorelines with a combination of cover and open basking areas. Critically, careful attention needs to be paid to managing water depth so that over-wintering sites remain viable.
\end{abstract}

Key words: Chrysemys picta bellii; Western Painted Turtle; habitat selection; urban ecology; radio telemetry

\section{Introduction}

Currently, more than $80 \%$ of Canadians reside in urban centres (Statistics Canada 2011). As a result, urban habitats are becoming increasingly fragmented and urban planners are challenged with designing and maintaining urban parks that can sustain healthy, native wildlife populations. Turtles have long life histories, characterized by slow somatic growth rates and late age at maturity, leading to slow population growth (Brooks et al. 1990). Small changes to the aquatic and terrestrial habitats of turtles, such as draining, dredging, and shoreline development, can affect their survival. Increases in adult mortality by even $2-3 \%$ per year can lead to drastic population declines and possible local extinction (Congdon et al. 1993; Gibbs and Shriver 2002). Urbanization impacts turtle populations by decreasing genetic diversity (Rubin et al. 2001), restricting aquatic mobility (Bennett et al. 2010), increasing adult mortality (Marchand and Litvaitis 2004; Aresco 2005; Gibbs and Steen 2005; Steen et al. 2006), increasing human disturbance (Pittfield and Burger 2017), and increasing rates of nest predation (Baldwin et al. 2004; Marchand and Litvaitis 2004). All of these factors are exacerbated at northern latitudes where climate may be an additional factor affecting turtle population parameters (i.e., shorter growing season, slowed annual somatic growth rate, further delayed age at maturity).
Previous studies have focussed on the detrimental impacts of urbanization for turtle population persistence; however, few studies examine critical features influencing persistence in urban environments (e.g., Spinks et al. 2003; Plummer and Mills 2008; Winchell and Gibbs 2016; Pittfield and Burger 2017). Urban systems are highly dynamic, creating continual changes to the surrounding environment. Knowledge of turtle resource requirements in response to external anthropogenic pressures is necessary as these requirements can vary temporally and spatially. Biologically relevant time periods and multiple spatial scales therefore need to be considered (Johnson 1980). Turtles are ectotherms, so their movement and habitat use are dictated by their thermal, metabolic, and reproductive needs. As such, their active season can be divided into three relevant time periods (emergence, nesting, and post-nesting), to better understand habitat selection and space use variation based on different phases of the seasonal cycle (Litzgus and Mousseau 2004; Rasmussen and Litzgus 2010). Knowledge of the core habitats and space required throughout the three phases of the active season is required to manage turtle habitat in urban systems.

Suitable overwintering habitat for adult turtles is a critical factor for northern populations over the longterm. At the extreme, turtles can spend four to six months under the ice, meaning that nearly half of their 
lifetime is spent in overwintering habitat (Ultsch 2006; Jackson and Ultsch 2010). Overwintering habitats are chosen in the fall, and must be adequate to ensure survival until the ice recedes in the spring. A thermally stable aquatic habitat enables reduced metabolism; however, overwintering locations can prove to be physiologically stressful or lethal by exposing individuals to severe risks such as freezing, predation, anoxia, and metabolic acidosis (Ultsch 2006). In urban environments, the risk of overwintering site selection can increase because water levels are often artificially controlled. Water level reduction during the winter can result in mortality (Bodie and Semlitsch 2000). To effectively manage populations, we need a thorough understanding of habitat requirements not only during the active season, but also during the winter. Within Canada, most studies focus on populations inhabiting relatively pristine environments (e.g., Edge et al. 2009; Rasmussen and Litzgus 2010; Millar and BlouinDemers 2011; Paterson et al. 2012). Few studies have examined overwintering habitat use in highly urban areas at northern latitudes.

Painted Turtles (Chrysemys picta) are one of the most widely distributed freshwater turtles in North America, reaching their northern limit throughout southern Canada. Painted Turtles typically inhabit shallow ponds, lakes, and slow-moving creek and river systems (Ernst and Lovich 2009; COSEWIC 2017). They are habitat generalists, able to adapt to their surrounding environment (Browne and Hecnar 2007) and are fairly tolerant of polluted waters (Ernst and Lovich 2009). Due to their wide range, and typically large population sizes in comparison to other freshwater turtles, Painted Turtles have become one of the most studied freshwater turtles in North America (Ernst and Lovich 2009; Lovich and Ennen 2013). Within Canada, many studies focus on Midland Painted Turtle (C. p. margina$t a)$ and examine aspects of their ecology and life history (e.g., Taylor and Nol 1989; Edwards and BlouinDemers 2007; Rollinson and Brooks 2007; Carrière et al. 2008; Rollinson et al. 2008). Western Painted Turtle (C. p. bellii) has received little attention in regards to habitat and space use (e.g., MacCulloch and Secoy 1983a; St. Clair and Gregory 1990; Basaraba 2014), and therefore habitat requirements are derived from studies on the other subspecies (COSEWIC 2017). Western Painted Turtles attain larger body sizes, and reach higher latitudes than the other subspecies (Ernst and Lovich 2009), therefore their habitat and space use may differ from the smaller subspecies.

Here we examine year-round habitat selection and space use by an urban population of Western Painted Turtles in Regina, Saskatchewan. This population is in a major urban centre near the northern range limit for all turtle species on the Great Plains. Little is known about Western Painted Turtle habitat selection and space use in the Saskatchewan prairie environment where populations face climatic and anthropogenic extremes.
We hypothesized that turtle movements and home range sizes of males and females would vary across the active season based upon the reproductive-strategies hypothesis (Morreale et al. 1984). Correspondingly, we predicted that males would make the largest movements during emergence to find mates, and females would make the largest movements during nesting to find suitable nesting habitat. For habitat selection, we hypothesized that certain habitat features are necessary for turtle survival and reproduction in an urban environment. We predicted that turtles would select for particular habitats that facilitate foraging, thermoregulation, mating, and nesting. We predicted that turtles would select overwintering sites with deeper water, higher temperature, and more dissolved oxygen, compared to those available.

\section{Study Area}

Our study occurred in the City of Regina, Saskatchewan $\left(50.417^{\circ} \mathrm{N}, 104.583^{\circ} \mathrm{W}\right)$, the provincial capital with over 214000 residents (Statistics Canada 2017). The regional climate is characterized by short, warm summers and long, cold winters, an average of 115 frostfree days, and average daily maximum temperatures of $25.8^{\circ} \mathrm{C}$ (extreme: $43^{\circ} \mathrm{C}$ ) in July and average daily minimum temperatures of $-20.1^{\circ} \mathrm{C}$ (extreme: $-50^{\circ} \mathrm{C}$ ) in January (Environment Canada 2010). The harsh climate on the northern Great Plains results in only a small number of turtle species. In Saskatchewan, Snapping Turtle (Chelydra serpentina) and Western Painted Turtle reach the northern limit of their ranges; however, Western Painted Turtles are more widespread with populations throughout much of southern Saskatchewan.

Our study site was in the Wascana Creek watershed that begins southeast of Regina and flows west before entering the Qu'Appelle River. The study area was approximately 1000 ha, and consisted of two major habitat areas: a human-made lake (between Albert St. and Broad St.) and marsh (between Broad St. and Ring Rd.), and a creek flowing into the marsh on the east and flowing out of the lake on the west (Figure 1). The depth of the lake was artificially increased twice by draining and dredging in 1931 (average depth $2 \mathrm{~m}$ ) and again during the winter of 2003-2004 (average depth $8 \mathrm{~m}$ ) to improve water quality (Hughes 2005). The area surrounding the study site is primarily large green spaces such as urban parks and golf courses, as well as residential and commercial development; four major roads cross the study area. Most of the surrounding vegetation was originally planted in the early 1900s (Hughes 2005), with the current terrestrial shoreline dominated by large willow trees (Salix spp.) and emergent aquatic vegetation, largely consisting of Broad-leaved Cattail (Typha latifolia L.).

We defined two main habitat areas for turtles within the study site, marsh (which included the lake) and creek, separated by a large-scale water control dam under the Albert Street bridge (Figure 1) that appeared to be a complete barrier to turtle movement (K.A.M. 


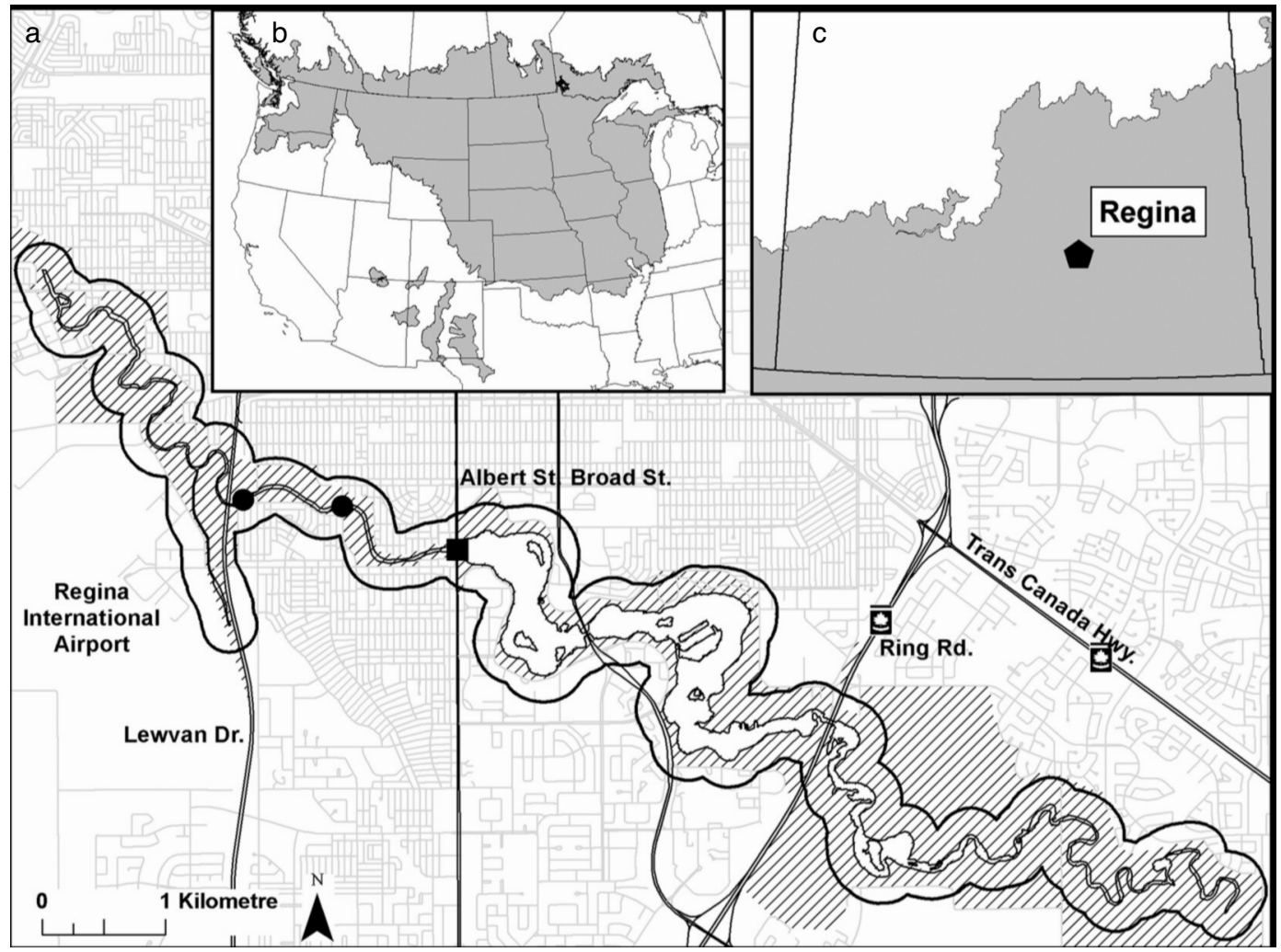

FIGURE 1. a. Study site in Regina, Saskatchewan showing the overall study area (1000 ha; black outline) indicating the barrier between the creek (West) and marsh/lake (East) habitat areas at Albert St. (square) and the two water control dams (circle) within the creek habitat. Hatched area indicates urban parkland. Insets display b. the North American range of Western Painted Turtle (Chrysemys picta bellii); and c. the location of the study area within Saskatchewan.

unpubl. data). Turtles caught west of the Albert Street bridge were deemed to be in creek habitat, and those caught east of the bridge were deemed to be in marsh habitat. The available habitat associated with the marsh and lake (water, shoreline, and $200 \mathrm{~m}$ urban buffer zone) was $\sim 677$ ha and $\sim 270 \mathrm{~m}$ wide. The marsh area is designated a Federal Migratory Bird Sanctuary, and is not open to the public but the lake is open to recreational users, primarily canoes and kayaks. The creek habitat was $\sim 325$ ha and $\sim 25 \mathrm{~m}$ wide with two water control dams. Few recreationists use the aquatic habitat but the surrounding parkland is used extensively.

\section{Methods}

\section{Turtle capture and tracking}

We captured turtles using a combination of hand capture, dip nets, and hoop traps baited with sardines, from April to September 2015 and 2016. Each individual was given a unique notch code that was filed into the marginal scutes of their carapace (Cagle 1939). Sex was determined using secondary sex characteristics (e.g., foreclaw length, pre-cloacal tail length, body size; Ernst and Lovich 2009). Individuals that did not display sec- ondary sex characteristics were classified as sub-adults or juveniles ( $<115 \mathrm{~cm}$ carapace length). Body measurements were recorded, including body size (mid-line carapace length $\pm 1 \mathrm{~mm})$, and mass $( \pm 1 \mathrm{~g})$. We attached radio transmitters (RI-2B, $14 \mathrm{~g}[n=25]$ and $6 \mathrm{~g}$ $[n=4]$; Holohil Systems Ltd., Ontario, Canada) to the rear marginal scutes using epoxy putty (Waterweld Epoxy Putty; J-B Weld, Texas, USA). The total mass of the unit (transmitter + epoxy) was $<15 \mathrm{~g}$ and represented $<5 \%$ of turtle body mass. In 2015 and 2016 , 23 turtles (marsh: 12 females, four males; creek: four females, three males) and 29 turtles (marsh: 14 females, eight males; creek: four females, three males), respectively, were outfitted with radio transmitters. Twentytwo turtles (17 females, five males) were tracked in both the 2015 and 2016 field seasons. All turtles were released at the point of capture within 30 minutes.

We tracked turtles from a canoe in the open water season, and on foot (on the ice) during winter, using a portable receiver (R1000; Communications Specialists, Inc., Orange, California, USA) and hand-held threeelement antenna. We relocated turtles throughout the year, separating the active season (May to September) 
into three biologically relevant time periods during which we examined temporal variation (Table 1). During the active season, turtles were relocated roughly every other day. For each turtle relocation, the date, time, universal transverse mercator (UTM) coordinates, and the dominant broad- and fine-scale habitat types were recorded (Table 2). We recorded locations using a handheld global positioning system unit (Garmin eTrex 20; Garmin Ltd., Olathe, Kansas, USA) uploaded to ArcGIS version 10.3.1 (ESRI, Redlands, California, USA). Individuals monitored for less than three consecutive months during either the 2015 or 2016 active season, or with less than six relocations per activity period, were excluded from the yearly and seasonal analyses, respectively.

\section{Population size estimate}

To estimate total population size encompassing both the marsh and creek habitat areas across the 2015 and
2016 field seasons we used a modified version of the Lincoln-Petersen method (Lincoln 1930; Chapman 1951; Lancia et al. 2005). To meet assumptions of this approach, data on hatchlings were omitted from the calculation. Additionally, multiple methods of capture (hand capture and hoop traps) were used to reduce capture bias of individuals within the population.

\section{Movement and home range size}

We calculated distance moved using the movement. pathmetrics function in Geospatial Modelling Environment version 0.7.4.0 (GME; Beyer 2015) which allowed us to estimate step length measurements between successive relocations for each individual during the active season. The step length measurements were divided by the number of days between relocations to provide a relative minimum daily distance moved (DDM) for each tracked individual (Rasmussen and Litzgus 2010). During winter 2017, we examined

TABLE 1. Date ranges and descriptions for the four biologically relevant seasons used to describe home-range size and assess habitat selection of Western Painted Turtles (Chrysemys picta bellii) in Regina, Saskatchewan during 2015 and 2016.

\begin{tabular}{|c|c|c|c|c|c|}
\hline Season & Year & $\begin{array}{l}\text { No. } \\
\text { turtles } \\
\text { tracked }\end{array}$ & $\begin{array}{l}\text { Relocation } \\
\text { frequency } \\
(\text { days } \pm \mathrm{SE})\end{array}$ & Duration & Description \\
\hline Emergence & $\begin{array}{l}2015 \\
2016\end{array}$ & $\begin{array}{l}11 \\
28\end{array}$ & $\begin{array}{l}2 \pm 0 \\
4 \pm 0\end{array}$ & $\begin{array}{l}11 \text { May-28 May } \\
9 \text { April-19 May }\end{array}$ & $\begin{array}{l}\text { Emergence from overwintering sites until the first } \\
\text { gravid female was found (determined by palpation } \\
\text { of the rear leg pocket) }\end{array}$ \\
\hline Nesting & $\begin{array}{l}2015 \\
2016\end{array}$ & $\begin{array}{l}22 \\
28\end{array}$ & $\begin{array}{l}2 \pm 0 \\
2 \pm 0\end{array}$ & $\begin{array}{l}29 \text { May-8 July } \\
20 \text { May-5 July }\end{array}$ & Continues until females are no longer found gravid \\
\hline Post-nesting & $\begin{array}{l}2015 \\
2016\end{array}$ & $\begin{array}{l}23 \\
23\end{array}$ & $\begin{array}{l}3 \pm 0 \\
3 \pm 0\end{array}$ & $\begin{array}{l}9 \text { July-3 September } \\
6 \text { July-10 September }\end{array}$ & Following nesting until return to overwintering areas \\
\hline $\begin{array}{l}\text { Fall }(\mathrm{F}) / \\
\text { Winter (W) }\end{array}$ & 2015 & $\begin{array}{l}18 \\
15\end{array}$ & $\begin{aligned} \text { F: } 7 & \pm 0 \\
\text { W: } 30 & \pm 0 \\
F: & 14 \\
\text { W: } 30 & \pm 0\end{aligned}$ & $\begin{array}{l}4 \text { September-8 April } \\
10 \text { September-7 April }\end{array}$ & Movements within overwintering sites \\
\hline
\end{tabular}

TABLE 2. Definitions for large-scale and fine-scale habitat features used in the compositional analysis of Western Painted Turtle (Chrysemys picta bellii) habitat in Regina, Saskatchewan. Broad-scale habitat was examined at second-order habitat selection, and fine scale habitat was examined at third-order habitat selection (Johnson 1980). Note: $\mathrm{M}=\mathrm{marsh}, \mathrm{C}=\mathrm{creek}$.

\begin{tabular}{|c|c|c|c|}
\hline Feature type & $\begin{array}{l}\text { Habitat } \\
\text { type }\end{array}$ & Description & $\begin{array}{c}\text { Percent } \\
\text { of habitat }(\%)\end{array}$ \\
\hline \multirow[t]{3}{*}{ Broad-scale } & Shoreline & $15 \mathrm{~m}$ zone on either side of the delineated shoreline & 15.0 \\
\hline & Urban/Parkland & $\begin{array}{l}200 \mathrm{~m} \text { zone around the study area (Steen } \text { et al. } 2012 \text {; } \\
\text { COSEWIC 2017) }\end{array}$ & 74.0 \\
\hline & Open water & Open water remaining between shoreline buffer areas & 17.0 \\
\hline \multirow[t]{5}{*}{ Fine-scale } & Barrier & $\begin{array}{l}\text { Human-made vertical barrier preventing shoreline } \\
\text { access for turtles }\end{array}$ & $\begin{array}{r}\mathrm{M}: 6.0 \\
\mathrm{C}: 3.5\end{array}$ \\
\hline & Cattails & Shoreline dominated by cattail vegetation & $\begin{array}{r}\text { M: } 60.3 \\
\mathrm{C}: 28.6\end{array}$ \\
\hline & No vegetation & $\begin{array}{l}\text { Shoreline consists of open beach area; either } \\
\text { cobblestones, soil, or sand }\end{array}$ & $\begin{array}{r}\mathrm{M}: 7.4 \\
\mathrm{C}: 0.5\end{array}$ \\
\hline & Shrubs & $\begin{array}{l}\text { Shoreline dominated by short, dense shrub vegetation; } \\
\text { no visible bank }\end{array}$ & $\begin{array}{l}\text { M: } 11.0 \\
\text { C: } 31.5\end{array}$ \\
\hline & Trees & $\begin{array}{l}\text { Shoreline dominated by large overhanging trees } \\
\text { (typically willow); bank always visible }\end{array}$ & $\begin{array}{l}\text { M: } 15.3 \\
\text { C: } 35.9\end{array}$ \\
\hline
\end{tabular}


turtle movement under the ice by measuring the straightline distance between successive relocations in ArcGIS. We deployed a reference transmitter attached to a rock in the overwintering area to use as a control to confirm turtle movement.

We determined the home range of individuals by calculating the $100 \%$ minimum convex polygon (MCP) using the genmcp function in GME, which provides the smallest possible convex polygon that encompasses all relocations for a particular individual or group of individuals (Row and Blouin-Demers 2006). We chose MCPs over other home range metrics (e.g., kernel density) because they eliminate the effect of autocorrelation, reduce the number of arbitrary choices required in the analysis (e.g., smoothing factor), and encompass areas that may be used as movement corridors and, thus, are excluded when using kernel density estimates (Row and Blouin-Demers 2006; Rasmussen and Litzgus 2010; Markle and Chow-Fraser 2014).

All active season movement and home range data were analyzed to determine effects of season, sex, habitat area, and year on movement rates and home range size using two separate generalized linear mixed models (GLMM; Gamma distribution). The fixed effects included season, sex, habitat area, and year. The random effect was turtle ID to account for repeated measures of each individual. A $\chi^{2}$ test was completed to examine the effect of the interaction between season and sex. Analyses were conducted using the lme4 package (Bates et al. 2015) in R version 3.3.1 (R Core Team 2016) and assumed a significance level of $P<0.05$. We report the mean $\pm \mathrm{SE}$ where appropriate.

\section{Habitat selection}

We examined habitat selection using compositional analysis at two spatial scales representing two categories in Johnson's (1980) hierarchy to determine whether the turtles select particular habitats disproportionately compared to what was available (Aebischer et al. 1993): broad-scale representing second-order selection and fine-scale representing third-order selection (Table 2). Second-order habitat selection was assessed by comparing the proportion of relocations of each individual turtle to the proportion of broad-scale habitat features available within the MCP for the entire population. Third-order habitat selection was assessed by comparing the proportion of relocations of each individual turtle within each section of the active season to the proportion of habitat features available within individual active season MCPs. Compositional analyses were completed using the compana function in the adehabitatHS package in R (Calenge 2006). In cases where habitat types were available but not used, we replaced the zero value with a value one order of magnitude smaller than the smallest non-zero number in the dataset (Aebischer et al. 1993).

\section{Overwintering site selection}

During the winter of 2015-2016 and 2016-2017, we determined overwintering locations for 19 turtles (15 marsh, four creek), and 18 turtles (14 marsh, four creek), respectively. Due to ice safety concerns, only turtles located within the marsh habitat between Broad Street and Ring Road were monitored throughout the winter months. We measured environmental variables at used and available overwintering sites from January to March by drilling holes through the ice using an auger. We chose representative used sites that were centrally located near groups of turtles with transmitters, and at least $15 \mathrm{~m}$ apart from other sites used for overwintering. We designated representative sites used in this way to avoid drilling through the ice directly above each turtle, potentially causing disturbance. At each site, a hole was augured into the ice and environmental variables were recorded including distance from shore $(\mathrm{m})$, water depth $(\mathrm{cm})$, ice thickness $(\mathrm{cm})$, water temperature $\left({ }^{\circ} \mathrm{C}\right)$, and dissolved oxygen level $(\mathrm{mg} / \mathrm{L})$. Both water temperature and dissolved oxygen level were measured using a YSI probe (YSI Pro Plus; YSI Inc., Yellow Springs, Ohio, USA). To examine differences in the sites used for overwintering compared to areas within the known overwintering habitat, we sampled available sites $10 \mathrm{~m}$ in each cardinal direction from the selected sites, as well as $30 \mathrm{~m}$ and $50 \mathrm{~m}$ west from the selected sites. To examine why the turtles selected their overwintering location versus another location available to them in the marsh habitat, we compared the sites used for overwintering to 12 randomly selected available sites. The randomly selected available sites were generated in ArcGIS using the Random Points function in the Data Management Toolbox.

To examine overwintering habitat selection, two separate GLMMs were constructed to examine the relationship between measured environmental variables and several fixed variables: within the known overwintering habitat and across the marsh habitat. Fixed variables included sample month, sample year, and location type (used or available). Environmental variables were recorded monthly during the winter of 2016 and 2017, so site ID was used as a random effect to account for repeated measures. This approach enabled testing the hypothesis that environmental variables differed between used and available overwintering sites. Analyses were conducted using the lme 4 package in $\mathrm{R}$ assuming a significance of $P<0.05$. We report the mean $\pm \mathrm{SE}$ where appropriate.

\section{Results}

\section{Population size assessment}

We captured 85 turtles (26 males, 43 females, eight juveniles, and eight neonates) and recaptured 47 turtles (16 males, 31 females) in 2016 within the creek and marsh habitat. The majority of the individuals captured $(88 \%)$ were from the marsh habitat, with only 10 individuals (six females, four males) found in the creek 
habitat. Most individuals were sexually mature adults with carapace length over $150 \mathrm{~mm}$. Using the LincolnPetersen method, we estimated the total population size to be 82 individuals $( \pm 8 ; 95 \% \mathrm{CI})$, resulting in a density of 0.3 turtles/ha within available shoreline and open water habitat with the marsh and the creek areas combined.

\section{Movements and home range}

Across the 2015 and 2016 field seasons, the average daily distance moved was $96 \pm 8 \mathrm{~m}$ and $172 \pm 6 \mathrm{~m}$ for the creek and marsh areas, respectively. The average distance that female turtles moved into upland habitat was $36 \pm 10 \mathrm{~m}$. The upland movements primarily occurred during nesting season. The maximum distance travelled into upland habitat was a female who moved $265 \mathrm{~m}$ in late July to reach a water retention pond near a golf course where she remained until fall. One male moved into upland habitat $(200 \mathrm{~m})$, but returned to the aquatic habitat by the next relocation. It is unclear what caused the upland movement; however, based on relocation frequency he may have spent a maximum of three days outside the creek habitat. Daily movement rates did not differ between the $2015(162 \pm 7 \mathrm{~m})$ and $2016(153 \pm 7 \mathrm{~m})$ active seasons $\left(t_{1}=0.14, P=0.9\right)$. There was no significant difference in the DDM between males and females $\left(t_{1}=1.7, P=0.09\right.$; Figure 2a). Marsh turtles moved longer distances compared to creek turtles $\left(t_{1}=11.5, P<0.01\right)$, with mean marsh turtle movements being two times longer compared to those in the creek (Figure 2b). Turtles moved longer distances during nesting $\left(t_{2}=7.6, P<0.01\right)$ and post- nesting $\left(t_{2}=4.6, P<0.01\right)$ seasons compared to during emergence (Figure 2c); however, there was no significant interaction between sex and season on $\operatorname{DDM}\left(\chi_{2}^{2}=\right.$ $4.1, P=0.1$; Figure 2d). During winter 2017, under ice movements were recorded. In February, turtles were found $4 \pm 0.8 \mathrm{~m}$ (control $=0 \mathrm{~m}$ ) from their January location. In March, turtles were found $20 \pm 5 \mathrm{~m}$ (control $=1 \mathrm{~m}$ ) from their February location.

Home ranges did not differ between 2015 and 2016 $\left(t_{1}=1.2, P=0.2\right)$. There was no significant difference between male and female home ranges $\left(t_{1}=0.35, P=\right.$ $0.7)$. The home ranges were significantly larger for the marsh turtles $(59 \pm 5$ ha) than the creek turtles $(19 \pm$ 4 ha; $\left.t_{1}=5.9, P<0.01\right)$. Across the active season, turtles had significantly larger home ranges during the nesting $\left(t_{2}=5.7, P<0.01\right)$ and post-nesting seasons $\left(t_{2}=7.2, P<0.01\right)$ compared to emergence, corresponding with increased DDM values. The interaction between sex and season did not affect turtle home range size $\left(\chi_{2}^{2}=2.8, P=0.3\right)$.

\section{Active season habitat selection}

Second-order habitat use was significantly non-ran$\operatorname{dom}$ (Wilk's $\lambda_{2}=0.06, P=0.002$ ). Shoreline habitat was used six times more than expected, accounting for $93 \%$ of the turtle relocations, and open water and urban/parkland were both used less than expected based on availability. At third-order, creek turtles used shoreline with no-vegetation 33-54 times more than expected based on availability during all three sections of the active season (Figure 3). Compositional analysis did not identify habitat use as significant (emergence: Wilk's
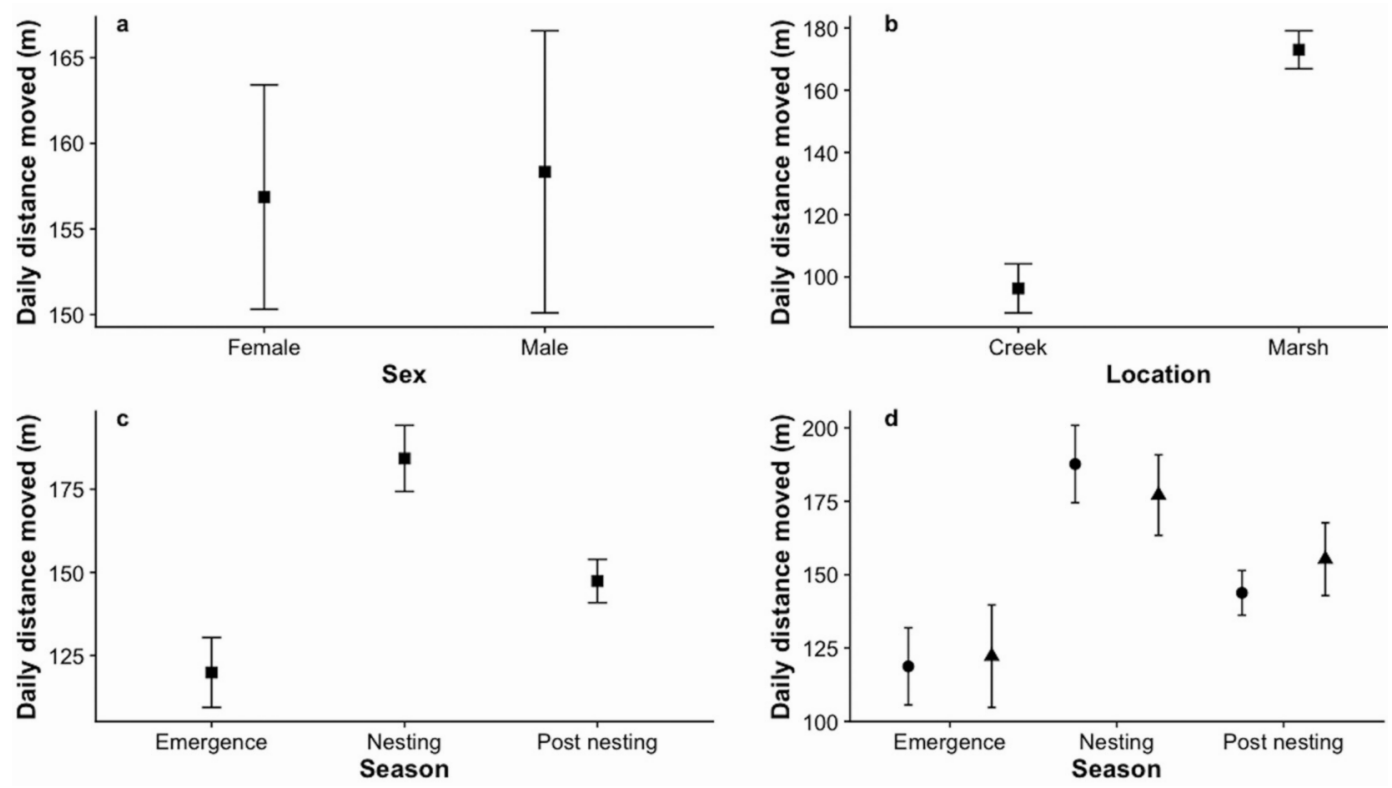

Figure 2. Mean ( \pm SE) daily distance moved for Western Painted Turtles (Chrysemys picta bellii) in Regina, Saskatchewan showing variation between a. sex, b. location, c. season, and d. females (circle) and males (triangle) across the active season. 


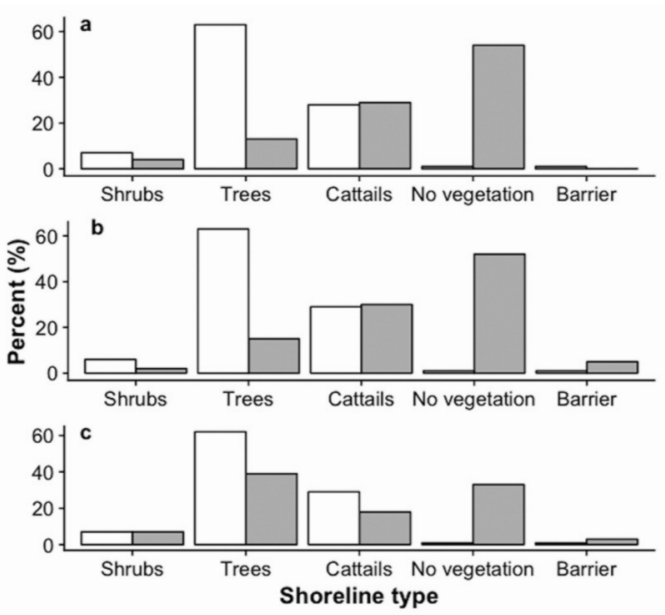

Figure 3. Proportion of used (grey) and available (white) shoreline habitat types within the creek habitat area during a. emergence, b. nesting, and c. post-nesting seasons.

$\lambda_{4}=0, P=1$; nesting: Wilk's $\lambda_{4}=0.02, P=0.09$; postnesting: Wilk's $\lambda_{4}=0.1, P=0.2$ ), which could be a result of a small sample size (Aebischer et al. 1993). In contrast, marsh turtles exhibited significant non-random habitat use across all three periods of the active season (emergence: Wilk's $\lambda_{4}=0.02, P=0.002$; nesting: Wilk's $\lambda_{4}=0.14, P=0.002$; post-nesting: Wilk's $\lambda_{4}=0.1, P=$ 0.002 ), with shorelines consisting of trees, shrubs, and cattails being used more than expected, and no-vegetation and barrier shorelines being used less than expected based on availability. Treed shoreline accounted for on average $51 \%$ of the relocations within each period of the active season, and was selected for 1.3 times more than expected during emergence and two times more than expected during nesting and post-nesting based on availability. Within the emergence period, shrub shoreline accounted for $36 \%$ of the relocations and during both nesting and post-nesting periods, cattail shoreline accounted for $32 \%$ and $22 \%$ of relocations, respectively.

\section{Overwintering site selection}

During 2016 and 2017, the marsh habitat had approximately 142 and 136 days of ice cover, respectively. Turtles $(n=13)$ overwintered between a pair of islands along the east shore, $7 \pm 0.5 \mathrm{~m}$ from the shoreline in 2016 and $9 \pm 0.4 \mathrm{~m}$ from the shoreline in 2017 . On average across the two years, the sites used for overwintering experienced dissolved oxygen levels of $3.8 \pm 0.97 \mathrm{mg} / \mathrm{L}$ (minimum: $0.6 \mathrm{mg} / \mathrm{L}$ ), water temperature of $1.6 \pm 0.22^{\circ} \mathrm{C}$ (minimum: $0.1{ }^{\circ} \mathrm{C}$ ), and water depths of $148 \pm 14 \mathrm{~cm}$ (minimum: $53 \mathrm{~cm}$ ). Within the immediate overwintering habitat there were no significant differences in water temperature $\left(t_{1}=-0.98, P=\right.$ $0.3)$, dissolved oxygen level $\left(t_{1}=0.74, P=0.5\right)$, or water depth $\left(t_{1}=-1.4, P=0.2\right)$ between the sites used for overwintering and the randomly selected available sites. All sites within the immediate overwintering area exhibited temporal variation. In 2017, the dissolved oxygen levels were significantly higher $(4 \pm 4 \mathrm{mg} / \mathrm{L}$; $\left.t_{1}=5.7, P<0.01\right)$, the water temperatures were significantly lower $\left(1.5 \pm 0.6^{\circ} \mathrm{C} ; t_{1}=-11.3, P<0.01\right)$, and the water depths were significantly shallower $(195 \pm$ $\left.82 \mathrm{~cm} ; t_{1}=-1.4, P<0.01\right)$ compared to 2016 . Across both years, the dissolved oxygen levels were significantly higher $\left(t_{2}=12.4, P<0.01\right)$, the water temperatures significantly higher $\left(t_{2}=11.8, P<0.01\right)$, and the water depth significantly lower $\left(t_{2}=-3.5, P<0.01\right)$ in March compared to January and February.

Sites used for overwintering were significantly warmer $\left(t_{1}=2.4, P=0.02\right)$ and deeper $\left(t_{1}=2.3, P=0.02\right)$ than randomly selected available sites; but there was no significant difference in the dissolved oxygen levels $\left(t_{1}=-0.34, P=0.7\right.$; Figure 4$)$. Over the course of the winter, multiple available sites froze to the bottom (2016: $n=3$; 2017: $n=9$ ); however, sites used for overwintering did not freeze to the bottom. Water temperatures were significantly lower $\left(t_{1}=-3.5, P<0.01\right)$, and water depths significantly shallower $\left(t_{1}=-6.5, P<0.01\right)$ in 2017 compared to 2016. Across both years, dissolved oxygen levels were significantly higher in March $\left(t_{2}=\right.$ $4.1, P<0.01)$ compared to January and February, and water depths were significantly deeper in January $\left(t_{2}\right.$ $=3.7, P<0.01)$ compared to February and March.
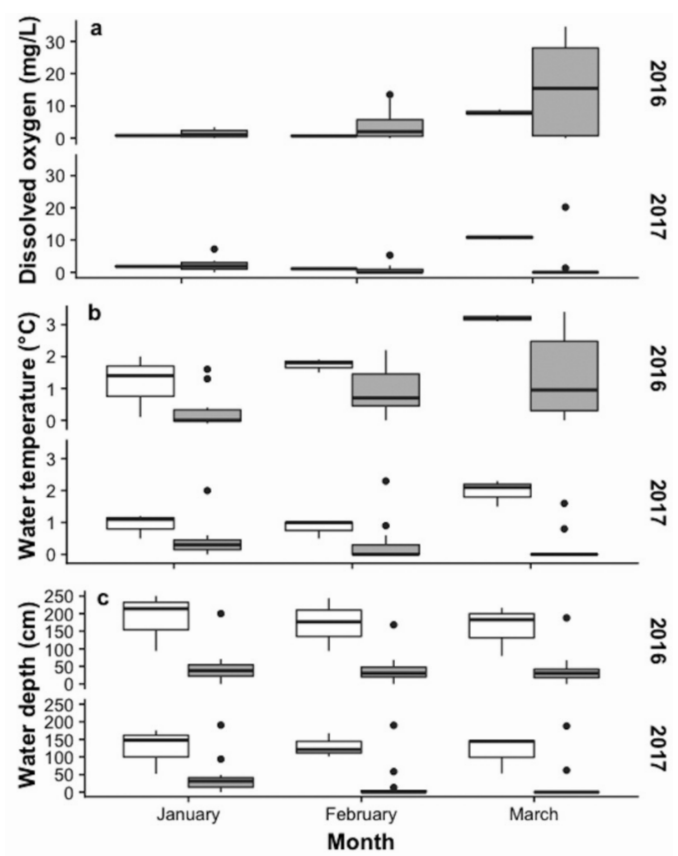

Figure 4. Boxplots of a. dissolved oxygen, b. water temperature, and c. water depth recorded at used (white; $n=3$ ) and available (random: grey; $n=12$ ) sites during the winter of 2016 and 2017. The median is depicted as the horizontal black line, boxes represent the 25 th and 75 th percentiles, whiskers depict the highest and lowest values, and the black circles represent outliers. 


\section{Discussion}

Population size assessment

We estimated the population to be $82( \pm 8)$ individuals, at a density of 0.3 turtles/ha, which was lower than typically recorded for this species. Painted Turtles are one of the most abundant freshwater turtle species within their range (Ernst and Lovich 2009), with some populations attaining sizes of over 3000 individuals (828 turtles/ha; Frazer et al. 1991). At the northern range limit in Canada, reported population sizes for Western Painted Turtles are sparse. However, a population inhabiting a water reservoir in Revelstoke, British Columbia was estimated to be approximately 242 individuals (2 turtles/ha; Basaraba 2014), and a population inhabiting the Qu'Appelle River north of Regina was estimated to be 167 individuals (11 turtles/ha; MacCulloch and Secoy 1983b). Both of these estimates are two- to threetimes larger than the estimate for our study population, indicating that our study site has a lower population density than reported populations.

The majority of turtles captured during the study were sexually mature individuals over $150 \mathrm{~mm}$ carapace length. We captured few juveniles and subadults. Within the total study population, female turtles occurred more commonly than males by approximately a 2:1 ratio (43 females: 26 males). The high capture rate of sexually mature individuals may be the result of sampling bias, as juveniles are cryptic and difficult to capture in the traps we deployed, or an indication of low productivity and recruitment. An age shift towards adults has been previously observed in freshwater turtle populations that have been affected by anthropogenic changes (Garber and Burger 1995; Saumure and Bider 1998; Browne and Hecnar 2007). Over the two years, we only observed one successful nest (eight hatchlings), and many were found predated, mostly by Richardson's Ground Squirrels (Urocitellus richardsonii). This was the first assessment of population size for this study area, so temporal comparisons are not possible. However, the information gathered in the current study can be used as a baseline for future population monitoring.

\section{Turtle movements and home range}

Western Painted Turtles in this study did not conform to predictions about seasonal movements based upon the reproductive strategies hypothesis. We found that turtle movements and space use did not differ between sexes and that variation was more attributable to the season in which the movements occurred, with both sexes exhibiting decreased movement and space use during emergence in comparison to nesting and postnesting phases of the active season. This pattern may reflect metabolic requirements as well as a response to environmental temperatures, as activity does not begin until water levels reach approximately $10^{\circ} \mathrm{C}$ (Ernst 1971). During emergence, Painted Turtles spend increased time basking allowing them to conserve energy, increase their body temperature following emergence, and overcome acidosis experienced during overwintering (Congdon 1989; Edwards and Blouin-Demers 2007; Carrière et al. 2008; Millar and Blouin-Demers 2011). Freshwater turtles such as Spotted Turtle (Clemmys guttata; Litzgus and Mousseau 2004) and Blanding's Turtle (Emydoidea blandingii; Millar and BlouinDemers 2011) communally aggregate following hibernation, which reduces the requirement of males to actively seek females throughout the habitat. Therefore, the mixed-sex basking aggregations observed in our study population could explain the limited movements of males in contrast to the reproductive strategies hypothesis. Movements and space use increased during nesting and post-nesting phases. In addition to coinciding with warmer seasonal temperatures, this increased activity is likely related to increased efforts in searching for desired nesting habitat, food resources, or potential mates.

Movements into upland habitat were only documented during the nesting season. In contrast to previous studies (e.g., McAuliffe 1978; Bowne 2008), we did not document turtles making large overland movements to reach alternate habitat, as the majority of relocations were confined to shoreline and open water. During the nesting season, females moved into upland habitat on average $<50 \mathrm{~m}$ from the shoreline. However, despite this very limited upland movement, females still came into contact with roads. Three females $(7 \%$ of captured females) were hit by vehicles, two of which were found to be gravid, a mortality rate which, if continued, exceeds a sustainable annual loss to our study population (Brooks et al. 1990; Congdon et al. 1993; Gibbs and Shriver 2002). One additional female was documented nesting in a gravel back alley roadway $\sim 25 \mathrm{~m}$ from the creek, an area bordered by residential houses and small parkland. Steen et al. (2012) found that Painted Turtles typically nest within $200 \mathrm{~m}$ of the shoreline. However, the distance travelled decreases in disturbed habitat, with females opting to nest in close proximity to the shoreline (Baldwin et al. 2004; Foley et al. 2012), which is consistent with findings in our study.

The average home range size and daily distance moved for Western Painted Turtles in our study were typical for that of the species in other parts of its range. The average home range size for turtles in both the marsh and the creek habitat areas are comparable to those reported in British Columbia, Tennessee, Ohio, and Pennsylvania (Saba and Spotila 2003; Tran et al. 2007; Jaeger and Cobb 2012; Basaraba 2014). In contrast, our home range estimates are 4-12 times larger than that reported for the Qu'Appelle River population north of Regina (MacCulloch and Secoy 1983a). This comparison should be interpreted with caution given the different survey methods used in the two studies. Marsh turtles had significantly larger movement rates and space use in comparison to the creek turtles. Previous studies have found a link between animal space use and the amount of habitat available (Schubauer et al. 
1990; Plummer et al. 1997; Jaeger and Cobb 2012). Animals with less available habitat by necessity have smaller home ranges compared to those with more available habitat. Therefore, the observed variation in our system may not be attributed to activity level differences, but rather the space available to the individuals within them.

\section{Active season habitat selection}

Turtles across our study area selected strongly for shoreline areas; however, the features of the shoreline selected varied between marsh and creek. For example, at the level of third order habitat selection, turtles in the marsh were found to select for treed shorelines, whereas turtles in the creek preferred shorelines with no vegetation. The habitat preferences turtles exhibited were consistent with studies on other Painted Turtle subspecies; they are commonly associated with shoreline habitats (Rowe and Dalgarn 2010) and they are most commonly found on shorelines with partial cover and suitable basking areas (Pittfield and Burger 2017). In contrast to other freshwater turtles (e.g., Litzgus and Mousseau 2004; Markle and Chow-Fraser 2014), Western Painted Turtles did not shift habitat selection throughout the active season. Within the Regina urban environment, turtles may prefer to use habitat with increased protection from human disturbance, while at the same time meeting their needs as ectotherms (i.e., basking). Additionally, suitable habitat may be limited in our system, as most natural shoreline features are represented in low proportions.

\section{Overwintering site selection}

Individuals displayed high site fidelity to one overwintering area, indicating that this overwintering location may be particularly important for our study population. The area used for overwintering was the single protected area that was not drained for the large-scale dredging event through the winter of 2004. In the winters of 2015-2016 and 2016-2017, all monitored turtles returned to the same $90 \mathrm{~m}$ section of shoreline, after being dispersed throughout the habitat during the active season. The high site fidelity to overwintering sites and the aggregation of turtles is consistent to what is observed in Spotted Turtles (Rasmussen and Litzgus 2010) and Snapping Turtles (Brown and Brooks 1994) at their northern range limits, where suitable overwintering habitat may be limited. We found that turtles selected sites close to shore, which would allow them to be exposed to warmer water earlier in the spring than deeper areas (Ultsch 1989). Overwintering movements were negligible through the winter, but by March some turtles began to move, perhaps to seek areas with increased dissolved oxygen levels produced by incoming melt water (Ultsch 1989).

The ranges of environmental conditions at the sites used for overwintering were similar to those documented for Western Painted Turtles in British Columbia (St.
Clair and Gregory 1990; Wood and Hawkes 2014) as well as for other subspecies across the range (Crawford 1991; Crocker et al. 2000; Rollinson et al. 2008). Contrary to what we expected, there was no support for the hypothesis that turtles selected sites based on dissolved oxygen levels in the water, as all used and available sites became hypoxic. However, they did select sites that were warmer and deeper compared to those randomly available to them. Lab data suggest that Painted Turtles can survive 118-150 days in anoxic conditions at $3^{\circ} \mathrm{C}$ (Reese et al. 2004; Jackson and Ultsch 2010), with Western Painted Turtles from northern populations better able to cope with the physiological effects of anoxia by accumulating less lactate than southern conspecifics and other subspecies (Reese et al. 2004). Therefore, similar to what was found in Blanding's Turtles in Ontario (Edge et al. 2009), choosing an overwintering location that will not freeze because of increased water depth and temperature may outweigh the risk of metabolic acidosis due to anoxia.

\section{Management implications}

Our data provide baseline information on population demographics and identify space use and habitat requirements of an urban population of Western Painted Turtles near the northern limit of the species range. The data we obtained from our study can serve as a baseline to document temporal changes in population size and habitat use. Through our study, we identified that overwintering habitat is critical to the persistence of this urban population. Turtles in our study population were found to move towards overwintering habitat by the beginning of September. A minimum of $2 \mathrm{~m}$ of water is required within $7-10 \mathrm{~m}$ of the shoreline in the core overwintering habitat, to ensure viable water temperatures over the winter. To ensure winter survival, water levels should not be dropped by more than $0.5 \mathrm{~m}$ through the winter, as this would cause overwintering sites to be compromised. Draining of Wascana Creek should be avoided. However, if depth management of Wascana Creek via dredging over the winter is found to be necessary, the core overwintering habitat should be protected so that it does not freeze solid or become drained of water.

The aquatic and terrestrial areas of the park should be managed to ensure a mosaic of shoreline habitats, which includes overhanging trees and submerged logs, to provide a protective buffer between the turtles and recreationists, and provide suitable basking areas to meet their thermal requirements. Shorelines dominated by concrete barriers and areas without vegetation cover should not be created as they will restrict shoreline access; however, they may be beneficial in high-risk areas (i.e., roadsides) to minimize risk of mortality. Finally, the majority of the population inhabits the eastern portion of the marsh, the Federal Migratory Bird Sanctuary. Public access to this section should continue to be restricted to minimize human disturbance. 


\section{Acknowledgements}

This research was supported by the Friends of Wascana Marsh, the Friends of the Royal Saskatchewan Museum, Wascana Centre Authority, the Saskatchewan Ministry of the Environment - Fish and Wildlife Development Fund, Nature Saskatchewan, Boggy Creek Wildlife Federation, Nature Regina, Regina Fish and Game League, the Natural Sciences and Engineering Research Council of Canada, the Canada Research Chairs Program, Canada Foundation for Innovation, and the University of Regina. We thank the University of Regina's Institute of Environmental Change and Society for in-kind support, and R.L. Eberts, A. Stulberg, J. Bos, and S. Turkeli for their assistance in the field. All animal work was carried out under the approved University of Regina President's Committee on Animal Care Protocol 15-03 and was authorized by an Academic Research Permit from the Saskatchewan Ministry of the Environment (permit number: 15FW075).

\section{Literature Cited}

Aebischer, N.J., P.A. Robertson, and R.E. Kenward. 1993. Compositional analysis of habitat use from animal radiotracking data. Ecology 74: 1313-1325. https://doi.org/10. 2307/1940062

Aresco, M.J. 2005. The effect of sex-specific terrestrial movements and roads on the sex ratio of freshwater turtles. Biological Conservation 123: 37-44. https://doi.org/10.10 16/j.biocon.2004.10.006

Baldwin, E.A., M.N. Marchand, and J.A. Litvaitis. 2004. Terrestrial habitat use by nesting painted turtles in landscapes with different levels of fragmentation. Northeastern Naturalist 11: 41-48. https://doi.org/10.1656/1092-6194(20 04)011[0041:THUBNP]2.0.CO;2

Basaraba, N.R.C. 2014. The ecology of western painted turtles (Chrysemys picta bellii) in a northern Canadian reservoir. M.Sc. thesis, Thompson Rivers University, Kamloops, British Columbia, Canada.

Bates, D., M. Maechler, B. Bolker, and S. Walker. 2015. Fitting linear mixed-effects models using lme4. Journal of Statistical Software 67: 1-48. https://doi.org/10.18637/jss. v067.i01

Bennett, A.M., M. Keevil, and J.D. Litzgus. 2010. Spatial ecology and population genetics of Northern Map Turtles (Graptemys geographica) in fragmented and continuous habitats in Canada. Chelonian Conservation and Biology 9: 185-195. https://doi.org/10.2744/CCB-0824.1

Beyer, H.L. 2015. Geospatial Modelling Environment (v. 0.7.4.0). Accessed January 2016. http://www.spatialecol ogy.com/gme.

Bodie, J.R., and R.D. Semlitsch. 2000. Spatial and temporal use of floodplain habitats by lentic and lotic species of aquatic turtles. Oecologia 122: 138-146. https://doi.org/ 10.1007/PL00008830

Bowne, D.R. 2008. Terrestrial activity of Chrysemys picta in northern Virginia. Copeia 2008: 306-310. https://doi.org/ 10.1643/CE-06-224

Brooks, R.J., G.P. Brown, and D.A. Galbraith. 1990. Effects of a sudden increase in natural mortality of adults on a population of the common snapping turtle (Chelydra serpentina). Canadian Journal of Zoology 69: 1314-1320. https://doi.org/10.1139/z91-185

Brown, G.P., and R.J. Brooks. 1994. Characteristics of and fidelity to hibernacula in a northern population of snapping turtles, Chelydra serpentina. Copeia 1994: 222-226. https: //doi.org/10.2307/1446689

Browne, C.L., and S.J. Hecnar. 2007. Species loss and shifting population structure of freshwater turtles despite habitat protection. Biological Conservation 138: 421-429. https: //doi.org/10.1016/j.biocon.2007.05.008

Cagle, F.R. 1939. A system of marking turtles for future identification. Copeia 1939: 170-173. https://doi.org/10.2307/ 1436818

Calenge, C. 2006. The package "adehabitat" for the R software: a tool for the analysis of space and habitat use by animals. Ecological Modelling 197: 516-519. https://doi. org/10.1016/j.ecolmodel.2006.03.017

Carrière, M., N. Rollinson, A.N. Suley, and R.J. Brooks. 2008. Thermoregulation when the growing season is short: sex-biased basking patterns in a northern population of Painted Turtles (Chrysemys picta). Journal of Herpetology 42: 206-209. https://doi.org/10.1670/07-070R1.1

Chapman, D.G. 1951. Some properties of the hypergeometric distribution with applications to zoological censuses. University of California Publications in Statistics 1: 131159.

Congdon, J.D. 1989. Proximate and evolutionary constraints on energy relations of reptiles. Physiological Zoology 62: 356-373. https://doi.org/10.1086/physzool.62.2.30156175

Congdon, J.D., A.E. Dunham, and R.C. Van Loben Sels. 1993. Delayed sexual maturity and demographics of Blanding's turtles (Emydoidea blandingii): implications for conservation and management of long-lived organisms. Conservation Biology 7: 826-833. https://doi.org/10.1046/j. 1523-1739.1993.740826.x

COSEWIC (Committee on the Status of Endangered Wildlife in Canada). 2017. COSEWIC assessment and status report on the Western Painted Turtle Chrysemys picta bellii (Pacific Coast population, Intermountain-Rocky Mountain population and Prairie/Western Boreal-Canadian Shield population) in Canada. COSEWIC, Ottawa, Ontario, Canada. Accessed 17 May 2018. http://sararegistry.gc.ca/virtual _sara/files/cosewic/sr_Western Painted Turtle_2016_e.pdf.

Crawford, K.M. 1991. The winter environment of painted turtles, Chrysemys picta: temperature, dissolved oxygen, and potential cues for emergence. Canadian Journal of Zoology 69: 2493-2498. https://doi.org/10.1139/z91-352

Crocker, C.E., R.A. Feldman, G.R. Ultsch, and D.C. Jackson. 2000. Overwintering behavior and physiology of eastern painted turtles (Chrysemys picta picta) in Rhode Island. Canadian Journal of Zoology 78: 936-942. https://doi.org/ 10.1139/z00-032

Edge, C.B., B.D. Steinberg, R.J. Brooks, and J.D. Litzgus. 2009. Temperature and site selection by Blanding's Turtles (Emydoidea blandingii) during hibernation near the species' northern range limit. Canadian Journal of Zoology 87: 825834. https://doi.org/10.1139/Z09-073

Edwards, A.L., and G. Blouin-Demers. 2007. Thermoregulation as a function of thermal quality in a northern population of painted turtles, Chrysemys picta. Canadian Journal of Zoology 85: 526-535. https://doi.org/10.1139/Z07-037

Environment Canada. 2010. Canadian climate normals 1981-2010 station data: Regina international airport. Accessed 5 June 2017. https://tinyurl.com/yctz83pk. 
Ernst, C.H. 1971. Population dynamics and activity cycles of Chrysemys picta in southeastern Pennsylvania. Journal of Herpetology 5: 151-160. https://doi.org/10.2307/1562736

Ernst, C.H., and J.E. Lovich. 2009. Chrysemys picta, Painted Turtles. Pages 183-211 in Turtles of the United States and Canada. Edited by C.H. Ernst and J.E. Lovich. Second Edition. The Johns Hopkins University Press, Baltimore, Maryland, USA.

Foley, S.M., S.J. Price, and M.E. Dorcas. 2012. Nest-site selection and nest depredation of semi-aquatic turtles on golf courses. Urban Ecosystems 15: 489-497. https://doi. org/10.1007/s11252-012-0229-4

Frazer, N.B., J.W. Gibbons, and J.L. Greene. 1991. Growth, survivorship and longevity of painted turtles Chrysemys picta in a southwestern Michigan marsh. American Midland Naturalist 25: 245-258. https://doi.org/10.2307/2426229

Garber, S.D., and J. Burger. 1995. A 20 -year study documenting the relationship between turtle decline and human recreation. Ecological Applications 5: 1151-1162. https:// doi.org/10.2307/2269362

Gibbs, J.P., and W.G. Shriver. 2002. Estimating the effects of road mortality on turtle populations. Conservation Biology 16: 1647-1652. https://doi.org/10.1046/j.1523-1739. 2002.01215.x

Gibbs, J.P., and D.A. Steen. 2005. Trends in sex ratios of turtles in the United States: implications of road mortality. Conservation Biology 19: 552-556. https://doi.org/10.1111/ j.1523-1739.2005.000155.x

Hughes, B. 2005. The Big Dig: The Miracle of Wascana Centre. Centax Books, Regina, Saskatchewan, Canada.

Jackson, D.C., and G.R. Ultsch. 2010. Physiology of hibernation under the ice by turtles and frogs. Journal of Experimental Zoology 313A: 311-327. https://doi.org/10.1002/ jez.603

Jaeger, C.P., and V.A. Cobb. 2012. Comparative spatial ecologies of female painted turtles (Chrysemys picta) and red-eared sliders (Trachemys scripta) at Reelfoot Lake, Tennessee. Chelonian Conservation and Biology 11: 5967. https://doi.org/10.2744/CCB-0949.1

Johnson, D.H. 1980. The comparison of usage and availability measurements for evaluating resource preference. Ecology 61: 65-71. https://doi.org/10.2307/1937156

Lancia, R.A., W.L. Kendall, K.H. Pollock, and J.D. Nichols. 2005. Estimating the number of animals in wildlife populations. Pages 106-153 in Techniques for Wildlife Investigation and Management. Edited by C.E. Braun. Sixth Edition. The Wildlife Society, Bethesda, Maryland, USA.

Lincoln, F.C. 1930. Calculating waterfowl abundance on the basis of banding returns. U.S. Department of Agriculture, Circular Number 118, Washington, DC, USA.

Litzgus, J.D., and T.A. Mousseau. 2004. Home range and seasonal activity of Southern Spotted Turtles (Clemmys guttata): implications for management. Copeia 2004: 804-817. https://doi.org/10.1643/CH-04024R1

Lovich, J.E., and J.R. Ennen. 2013. A quantitative analysis of the state of knowledge of turtles of the United States and Canada. Amphibia-Reptilia 34: 11-23. https://doi.org/10. 1163/15685381-00002860

MacCulloch, R.D., and D.M. Secoy. 1983a. Movement in a river population of Chrysemys picta bellii in southern Saskatchewan. Journal of Herpetology 17: 283-285. https:// doi.org/10.2307/1563834

MacCulloch, R.D., and D.M. Secoy. 1983b. Demography, growth, and food of western painted turtles, Chrysemys picta bellii (Gray), from southern Saskatchewan. Canadian
Journal of Zoology 61: 1499-1509. https://doi.org/10.11 39/z83-202

Marchand, M.N., and J.A. Litvaitis. 2004. Effects of landscape composition, habitat features, and nest distribution on predation rates of simulated turtle nests. Biological Conservation 117: 243-251. https://doi.org/10.1016/j.biocon.2003. 07.003

Markle, C.E., and P. Chow-Fraser. 2014. Habitat selection by the Blanding's turtle (Emydoidea blandingii) on a protected island in Georgian Bay, Lake Huron. Chelonian Conservation and Biology 13: 216-226. https://doi.org/10. 2744/CCB-1075.1

McAuliffe, J.R. 1978. Seasonal migrational movements of a population of the western painted turtle, Chrysemys picta bellii (Reptilia, Testudines, Testudinidae). Journal of Herpetology 12: 143-149. https://doi.org/10.2307/1563400

Millar, C.S., and G. Blouin-Demers. 2011. Spatial ecology and seasonal activity of Blanding's Turtles (Emydoidea blandingii) in Ontario, Canada. Journal of Herpetology 45: 370-378. https://doi.org/10.1670/10-172.1

Morreale, S.J., J.W. Gibbons, and J.D. Congdon. 1984. Significance of activity and movement in the yellow-bellied slider turtle (Pseudemys scripta). Canadian Journal of Zoology 62: 1038-1042. https://doi.org/10.1139/z84-148

Paterson, J.E., B.D. Steinberg, and J.D. Litzgus. 2012. Generally specialized or especially general? Habitat selection by Snapping Turtles (Chelydra serpentina) in central Ontario. Canadian Journal of Zoology 90: 139-149. https:// doi.org/10.1139/z11-118

Pittfield, T., and J. Burger. 2017. Basking habitat use and response of freshwater turtles to human presence in an urban canal of central New Jersey. Urban Ecosystems 20: 449461. https://doi.org/10.1007/s11252-016-0606-5

Plummer, M.V., and N.E. Mills. 2008. Structure of an urban population of softshell turtles (Apalone spinifera) before and after severe stream alteration. Pages 95-105 in Urban Herpetology. Edited by R.E. Jung and J.C. Mitchell. Volume 3. Society for the Study of Amphibians and Reptiles, Salt Lake City, Utah, USA.

Plummer, M.V., N.E. Mills, and S.L. Allen. 1997. Activity, habitat, and movement patterns of Softshell Turtles (Trionyx spiniferus) in a small stream. Chelonian Conservation and Biology 2: 514-520.

R Core Team. 2016. R: A language and environment for statistical computing. R Foundation for Statistical Computing, Vienna, Austria.

Rasmussen, M.L., and J.D. Litzgus. 2010. Habitat selection and movement patterns of Spotted Turtles (Clemmys guttata): effects of spatial and temporal scales of analyses. Copeia 2010: 86-96. https://doi.org/10.1643/CE-09-141

Reese, S.A., E.R. Stewart, C.E. Crocker, D.C. Jackson, and G.R. Ultsch. 2004. Geographic variation of the physiological response to overwintering in the painted turtle (Chrysemys picta). Physiological and Biochemical Zoology 77: 619-630. https://doi.org/10.1086/383514

Rollinson, N., and R.J. Brooks. 2007. Proximate constraints on reproductive output in a northern population of painted turtles: an empirical test of the bet-hedging paradigm. Canadian Journal of Zoology 85: 177-184. https://doi.org/10. 1139/Z07-002

Rollinson, N., G.J. Tattersall, and R.J. Brooks. 2008. Overwintering habitats of a northern population of Painted Turtles (Chrysemys picta): winter temperature selection and dissolved oxygen concentrations. Journal of Herpetology 42: 312-321. https://doi.org/10.1670/07-1422.1 
Row, J.R., and G. Blouin-Demers. 2006. Kernels are not accurate estimators of home-range size for herpetofauna. Copeia 2006: 797-802. https://doi.org/10.1643/0045-8511 (2006)6[797:KANAEO]2.0.CO;2

Rowe, J.W., and S.F. Dalgarn. 2010. Home range size and daily movements of Midland Painted Turtles (Chrysemys picta marginata) in relation to body size, sex, and weather patterns. Herpetological Conservation and Biology 5: 461-473.

Rubin, C.S., R.E. Warner, J.L. Bouzat, and K.N. Paige. 2001. Population genetic structure of Blanding's turtles (Emydoidea blandingii) in an urban landscape. Biological Conservation 99: 323-330. https://doi.org/10.1016/S00063207(00)00198-1

Saba, V.S., and J.R Spotila. 2003. Survival and behavior of freshwater turtles after rehabilitation from an oil spill. Environmental Pollution 126: 213-223. https://doi.org/10.1016/ S0269-7491(03)00192-1

Saumure, R.A., and J.R. Bider. 1998. Impact of agriculture development on a population of wood turtles (Clemmys insculpta) in southern Quebec, Canada. Chelonian Conservation and Biology 3: 37-45.

Schubauer, J.P., J.W. Gibbons, and J.R. Spotila. 1990. Home range and movement patterns of slider turtles inhabiting Par Pond. Pages 223-232 in Life History and Ecology of the Slider Turtle. Edited by J.W. Gibbons. Smithsonian Institution Press, Washington, DC, USA.

Spinks, P.Q., G.B. Pauly, J.J. Crayon, and H.B. Shaffer. 2003. Survival of the western pond turtle (Emys marmora$t a$ ) in an urban California environment. Biological Conservation 113: 257-267. https://doi.org/10.1016/S0006-3207 (02)00392-0

Statistics Canada. 2011. 2011 Census of population: population, urban and rural, by province and territory (Canada). Accessed 5 June 2017. http://www.statcan.gc.ca/tables-tab leaux/sum-som/101/cst01/demo62a-eng.htm.

Statistics Canada. 2017. 2016 Census profile: Regina (population centre), Saskatchewan and Saskatchewan (province). Accessed 5 June 2017. http://www12.statcan.gc.ca/ census-recensement/2016/dp-pd/prof/index.cfm?Lang=E.

St. Clair, R.C., and P.T. Gregory. 1990. Factors affecting the northern range limit of painted turtles (Chrysemys picta): winter acidosis or freezing? Copeia 1990: 1083-1089. https://doi.org/10.2307/1446492
Steen, D.A., M.J. Aresco, S.G. Beilke, B.W. Compton, E.P. Condon, C. Kenneth Dodd, Jr., H. Forrester, J.W. Gibbons, J.L. Greene, G. Johnson, T.A. Langen, M.J. Oldham, D.N. Oxier, R.A. Saumure, F.W. Schueler, J.M. Sleeman, L.L. Smith, J.K. Tucker, and J.P. Gibbs. 2006. Relative vulnerability of female turtles to road mortality. Animal Conservation 9: 269-273. https://doi.org/10.1111/ j.1469-1795.2006.00032.x

Steen, D.A., J.P. Gibbs, K.A. Buhlmann, J.L. Carr, B.W. Compton, J.D. Congdon, J.S. Doody, J.C. Godwin, K.L. Holcomb, D.R. Jackson, F.J. Janzen, G. Johnson, M.T. Jones, J.T. Lamer, T.A. Langen, M.V. Plummer, J.W. Rowe, R.A. Saumure, J.K. Tucker, and D.S. Wilson. 2012. Terrestrial habitat requirements of nesting freshwater turtles. Biological Conservation 150: 121-128. https://doi. org/10.1016/j.biocon.2012.03.012

Taylor, G.M., and E. Nol. 1989. Movements and hibernation sites of overwintering painted turtles in southern Ontario. Canadian Journal of Zoology 67: 1877-1881. https://doi. org/10.1139/z89-268

Tran, S.L., D.L. Moorhead, and K.C. McKenna. 2007. Habitat selection by native turtles in a Lake Erie wetland, USA. American Midland Naturalist 158: 16-28. https://doi. org/10.1674/0003-0031(2007)158[16:HSBNTI]2.0.CO;2

Ultsch, G.R. 1989. Ecology and physiology of hibernation and overwintering among freshwater fishes, turtles, and snakes. Biological Reviews 64: 435-516. https://doi.org/10.1111/j. 1469-185X.1989.tb00683.x

Ultsch, G.R. 2006. The ecology of overwintering among turtles: where turtles overwinter and its consequences. Biological Reviews 81: 339-367. https://doi.org/10.1017/S14 64793106007032

Winchell, K.M., and J.P. Gibbs. 2016. Golf courses as habitat for aquatic turtles in urbanized landscapes. Landscape and Urban Planning 147: 59-70. https://doi.org/10.1016/ j.landurbplan.2015.11.001

Wood, C.M., and V.C. Hawkes. 2014. CLBMON-11B3 Revelstoke Reach painted turtle monitoring program: annual report - 2013. Okanagan Nation Alliance and LGL Limited Environmental Research Associates, Sidney, British Columbia, Canada.

Received 29 January 2018

Accepted 22 April 2018 